\title{
EFFECT OF DIFFERENT SOIL MOISTURE LEVELS \\ AND NITROGEN SOURCES ON LETTUCE YIELD (Lactuca sativa L.) UNDER SURFACE AND DRIP IRRIGATION SYSTEMS IN CLAY LOAM SOILS \\ Seham M. Ali ${ }^{1}$; T.A. Eid ${ }^{2}$ and A.M Abd Elhady ${ }^{2}$ \\ 1-Hort. Res. Inst., Agric. Res. Cent., Giza, Egypt \\ 2-Soil, Water and Environ. Res. Inst. Agric. Res. Cent., Giza, Egypt
}

\begin{abstract}
A field experiment was conducted at El-Kanater Horticultural Research Station in the two seasons of $2013 / 14$ and $2014 / 15$ to study the effect of two soil moisture levels (25\% and $50 \%$ of available soil moisture i.e. medium and dry) under drip and surface irrigation systems and three sources of $\mathrm{N}$ - fertilizers, namely urea $(46.5 \% \mathrm{~N})$, ammonium nitrate $(33.5 \% \mathrm{~N})$ and ammonium sulphate $(20.5 \% \mathrm{~N})$ at the rate of $50 \mathrm{~kg}$ $\mathrm{N} /$ fed., as well as their interactions on applied irrigation water, water use efficiency, growth, yield quality and chemical composition of lettuce (Lactuca sativa L.) cv. Balady

Results indicate that surface irrigation system showed higher applied irrigation water under $25 \%$ and $50 \%$ of the available soil moisture than the drip irrigation system during 2013/14 and 2014/15 seasons. Drip irrigation system supported an increase of water use efficiency $\left(23.84\right.$ and $\left.22.57 \mathrm{~kg} / \mathrm{m}^{3}\right)$ in the first and the second seasons, respectively. Ammonium sulphate application slightly increased the water use efficiency W.U.E $\left(23.65\right.$ and $\left.24.16 \mathrm{~kg} / \mathrm{m}^{3}\right)$ in the two seasons, respectively. Results of the interaction indicate that the medium moisture (25\%) and Ammonium sulphate application under drip and surface irrigation systems increased all studied growth characters, yield and nutrient uptake of lettuce .
\end{abstract}

Keywords : Lettuce, soil moisture levels, nitrogen sources, growth ,yield

\section{INTRODUCTION}

Lettuce (Lactuca sativa) is consider one of the most important vegetable crops for fresh consumption in Egypt. It is commonly grown on the clay loam and clay soils under irrigated conditions. Literature on the water consumptive use and the influence of different water regimes on the yield and nitrogen uptake by lettuce are still insufficient. Water is consumed plentifully for agricultural purposes in Egypt and in the world (approximately 80\%). Available water for agriculture in Egypt is becoming a major constraint in the next few years. Therefore, maximizing its use can be carried out through the efficiency of modern irrigation systems (Brown, 1999). Efficient water use by irrigation systems is becoming increasingly important especially in arid and semi-arid regions with limited water resources. In agricultural practice, the sufficient and balanced application of irrigation water and nutrients are important methodology to obtain maximum yield per unit area. lettuce yield increased in response to water and nitrogen Sanchez (2000). On the other hand, excessive application of irrigation water and nutrients result in some serious problems (Türkmen et al., 2004). To reach optimal use of water 
resources, contribute to sustainable agriculture and to decrease or to eliminate the negative effects of irrigation to the ecology, the main objective of irrigation is to apply the water only as a plant needs for optimal use and to apply it on time to the active root zone depth with minimal water loss. Drip irrigation is considered to have many advantages over other types of irrigation (Thompson and Doerge, 1996 and Tan, 1995) .

Nevertheless, the rate of water consumption for industrial and domestic needs is gradually increasing and rate of water consumption for agricultural irrigation is decreasing that necessitate a more efficient use of available water resources. (Önder et al., 2005). Consequently, on loam soil, greater cantaloupe (Cucumis melo) yields were obtained for weekly irrigations compared to daily irrigations, higher onion yield for daily irrigations compared with weekly irrigations, and irrigation frequency had little effect on carrot (Daucus carota) yield (Bucks et al., 1980). Little irrigation frequency effect was found on cabbage (Brassica oleracea Capitata Group) yield for intervals of 3, 6 and 12 day on clay loam (Bucks et al., 1974). Also, higher potato (Solanum tuberosum) yield was found for more frequent drip irrigation, but no consistent trend was found for lettuce (Sammis, 1980).

Practices management that sustain lettuce production and improve soil and water quality are needed. Total $\mathrm{N}$ fertilizer recommendation for lettuce varies between 63 and $84 \mathrm{~kg} /$ fed. . Optimal N supply for lettuce increased the $\mathrm{N}$ residue at harvest in the soil, and thus the risk of nitrate leaching (Brumm and Schenk 1993). $\mathrm{N}$ and water required for maximum yields, $88 \%$ and $77 \%$ of the applied $\mathrm{N}$ were not recovered in the above ground portions of the plants, indicating the potential of large nitrate- $\mathrm{N}$ leaching in the soil Sanchez (2000). Therefore, the object of this study was to investigate the effect of some soil moisture levels and nitrogen sources on growth and yield of lettuce under drip and surface irrigation systems .

\section{MATERIALS AND METHODS}

Field experiment was carried out at El-Qanater Horticultural Research station, Kalubiya, Governorate during 2013/2014 and 2014/2015 seasons. Seeds of lettuce (Lactuca sativa L.) cv. Balady were cultivated in October $10^{\text {th }}$ for both seasons. Seeds were successfully germinated in the proper time. After germination by about $35-40$ days, seedlings $(8-10 \mathrm{~cm}$ long $)$. Were transplanted into experimental plots with area of about $12 \mathrm{~m}^{2}$ each plot contained 5 rows with length of $4 \mathrm{~m}$ and width of $0.6 \mathrm{~m}$ at $20 \mathrm{~cm}$ in between both sides of the ridges which were $60 \mathrm{~cm}$ apart and $20 \mathrm{~cm}$ between plants.

The time of transplanting took place $15^{\text {th }}$ and $20^{\text {th }}$ of November in both seasons, respectively. Harvesting was carried out on 20 and 26 January in the first and the second season, respectively. Vegetative and yield characteristics were measured using ten plants from each plot. Plant height, total yield, fresh weight of plant were measured with harvesting. The experiment was arranged in a split-plot design, with two irrigation methods as main plots and two irrigation regimens as sub plots and three sources of nitrogen fertilizer as sub sub plots with three replications. 
The soil on which the experiments were undertaken was a clay loam. Table 1 shows soil / water parameter and bulk density of the soil; Table 2 shows main properties of the soil. Meteorological data for the Agricultural Research Station are shown in Table 3.

Table (1): Field capacity wilting point, available water and bulk density of soilat various depths.

\begin{tabular}{|l|c|c|c|c|}
\hline Depths & $\begin{array}{c}\text { Field capacity } \\
\text { (F.C.) \% }\end{array}$ & $\begin{array}{c}\text { Wilting point } \\
\text { (WP) \% }\end{array}$ & $\begin{array}{c}\text { Available water } \\
\text { (AW) \% }\end{array}$ & $\begin{array}{c}\text { Bulk density } \\
\text { (BD) } \mathbf{~} / \mathbf{c m}^{\mathbf{3}}\end{array}$ \\
\hline $0-15$ & 37.9 & 18.1 & 19.8 & 1.27 \\
\hline $15-30$ & 36.1 & 17.6 & 18.5 & 1.30 \\
\hline $30-45$ & 33.5 & 16.9 & 16.6 & 1.31 \\
\hline $45-60$ & 32.5 & 16.2 & 16.3 & 1.34 \\
\hline
\end{tabular}

FC: moisture at $33 \mathrm{kPa}$ moisture tension. WP: moisture at $1.5 \mathrm{MPa}$ moisture tension. AW $=$ FC - WP

Table (2): Physical and chemical properties of the soil.

\begin{tabular}{|c|c|c|c|}
\hline Parameter & Value & Parameter & Value \\
\hline Particle size distribution (\%): & & EC (dS/m, soil paste extract) & 1.1 \\
\hline Clay $\%$ & 31.4 & Saturation percent & 67.5 \\
\hline Silt & 33.5 & \multicolumn{2}{|c|}{$\begin{array}{l}\text { Cations and anions in soil paste extract } \\
(\mathrm{mmolc} / \mathrm{L}) \text { : }\end{array}$} \\
\hline Fine sand & 34 & $\mathrm{Na}^{+}$ & 4.1 \\
\hline Coarse sand & 1.1 & $\mathrm{~K}^{+}$ & 0.41 \\
\hline Texture class & Clay loam & $\mathrm{Ca}^{++}$ & 3.07 \\
\hline $\mathrm{CaCO}_{3} \mathrm{~g} / \mathrm{kg}$ & 35.9 & $\mathrm{Mg}++$ & 2.63 \\
\hline Organic matter g / kg & 17 & $\mathrm{CO}_{3}{ }^{=}$ & 0 \\
\hline${ }^{\star}$ Available $\mathrm{K}$ mg / kg & 191.9 & $\mathrm{HCO}_{3}^{-}$ & 3.85 \\
\hline${ }^{\star}$ Available P mg / kg & 9.33 & $\mathrm{Cl}^{-}$ & 3.7 \\
\hline $\begin{array}{l}\mathrm{pH}(1: 2.5 \mathrm{w} / \mathrm{v} \text { soil water } \\
\text { suspension) }\end{array}$ & 7.9 & $\mathrm{SO}_{4}=$ & 2.66 \\
\hline
\end{tabular}

* Extracts of $\mathrm{NH}_{4}-$ acetate (for $\mathrm{K}$ ), and sodium bicarbonate (for $\mathrm{P}$ ).

The study concerned the use of different irrigation levels and nitrogen fertilizer sources on Lettuce (Lactuca sativa) crop.

\section{Irrigation treatments :} follows:

The investigation was designed to test two irrigation treatments as

1- Irrigation when $25 \%$ of available soil moisture is depleted $\left(I_{1}\right)$.

2- Irrigation when $50 \%$ of available soil moisture is depleted $\left(I_{2}\right)$.

irrigation systems: 1- Surface irrigation. 2- Drip irrigation.

Nitrogen treatments :

The sources of nitrogen fertilizer were urea ( $46 \% \mathrm{~N}$ ), ammonium nitrate, $(33.5 \% \mathrm{~N})$ and ammonium sulphate $(20.6 \% \mathrm{~N})$ at the rate of 50 $\mathrm{kg} / \mathrm{fed}$. Nitrogen fertilizers were added as two equal batches, after transplanting by two weeks and after three weeks later.

The plot area was $20 \mathrm{~m}^{2}$ planted in ridges, $70 \mathrm{~cm}$ part, and $15 \mathrm{~cm}$ between plants. All plots received $P 13 \mathrm{~kg} / \mathrm{fed}$. ordinary superphosphate 
$\left(15.5 \% \mathrm{P}_{2} \mathrm{O}_{5}\right)$. In addition, plots received $\mathrm{K}$ as potassium sulphate $\left(48 \% \mathrm{~K}_{2} \mathrm{O}\right)$ $50 \mathrm{~kg} / \mathrm{fed}$. Both $\mathrm{P}$ and $\mathrm{K}$ were applied in one dose during preparation of soil before lettuce transplanting .

Table (3): Meteorological data in 2013/214 and 2014/215 seasons.

\begin{tabular}{|l|c|c|c|c|c|c|c|}
\hline \multirow{2}{*}{ Month } & \multicolumn{7}{|c|}{$\mathbf{2 0 1 3 / 2 0 1 4}$} \\
\cline { 2 - 8 } & T.max. & T.min. & WS & RH & SS & SR & R. F \\
\hline October & 30.0 & 18.4 & 1.0 & 65 & 11.3 & 417 & 0.0 \\
\hline November & 27.2 & 14.6 & 0.8 & 67 & 10.5 & 326 & 0.0 \\
\hline December & 23.0 & 11.5 & 0.7 & 63 & 10.1 & 268 & 0.0 \\
\hline January & 20.9 & 8.5 & 3.0 & 56.1 & 6.6 & 280 & 0.3 \\
\hline & 30.7 & 17.1 & 3.3 & 47.2 & 7.3 & 417 & 0.0 \\
\hline October & 22.2 & 10.2 & 2.58 & 62.0 & 8.4 & 432 & 0.0 \\
\hline November & 27.2 & 14.2 & 2.58 & 60.0 & 9.5 & 514 & 0.0 \\
\hline December & 27.0 & 18.1 & 2.63 & 56.0 & 10.5 & 572 & 0.0 \\
\hline January & 32.8 & 18.1 &
\end{tabular}

T. $\max$, T. $\min =$ maximum and minimum temperatures ${ }^{\circ} \mathrm{C}$.

WS $=$ wind speed $(\mathrm{m} / \mathrm{sec})$.

$\mathrm{RH}=$ relative humidity (\%).

SS = actual sunshine duration (h/day)

$\mathrm{SR}=$ solar radiation $\left(\mathrm{cal} / \mathrm{cm}^{2} /\right.$ day)

$\mathrm{RF}=$ rainfall (mm / month).

\section{Drip irrigation system}

The drip irrigation system used in the farm included an irrigation pump (2 hp) connected to sand and screen filters and a fertilizer injector tank. The conveying pipeline system consists of a main line that is made of PVC pipe of $76.2 \mathrm{~mm}$ diameter connected to sub-main line of $50.8 \mathrm{~mm}$ and manifold of $38.1 \mathrm{~mm}$. The drip lateral lines of $16 \mathrm{~mm}$ diameter were connected to the manifold line. Each line is served by two lateral lines about $20 \mathrm{~cm}$ apart . Lateral lines were equipped with build-in emitters of $4 \mathrm{l} / \mathrm{h}$ discharge and spaced $0.50 \mathrm{~m}$ apart on the lateral line.

Amount of applied irrigation water (AIW):

1-Drip irrigation system:

The amount of applied water was measured by a flow meter and was calculated according to (FAO, 1984) as the following equation:

$$
A I W=\frac{S p X S_{l} X E T c X K r X I \text { int erval }}{E a}
$$

Where:

AIW = applied irrigation water depth

$\mathrm{Sp}=$ distance between plants in the same line $(\mathrm{m})$.

$\mathrm{S}_{\mathrm{I}}=$ distance between lines $(\mathrm{m})$.

$\mathrm{ET}_{\mathrm{c}}=$ water consumptive use.

$\mathrm{K}_{\mathrm{r}}=$ reduction factor that depends on ground cover. It equals 0.7 for (FAO, 1979).

$\mathrm{E}_{\mathrm{a}}=$ irrigation efficiency $=\mathrm{K}_{1} \times \mathrm{K}_{2}=0.80$

where:

$\mathrm{K}_{1}=$ emitter uniformity coefficient $=0.90$ for the experimental site . 
$\mathrm{K}_{2}=$ drip irrigation system efficiency $=0.89$ for the experimental site.

$\mathrm{I}_{\text {interval }}=$ irrigation intervals (days) $=1$ day for the experimental site.

2-Surface irrigation system: equation:

Depth of applied irrigation water was calculated according to the following

$$
A I W=\frac{E T c}{E a}
$$

Where:

$\mathrm{ET}_{\mathrm{c}}$ : water consumptive use $(\mathrm{mm} / \mathrm{d})$

$E_{a}$ : application efficiency (fraction) $=0.6$ for surface irrigation system .

Irrigation water applied (IWA):

Submerged flow orifice with fixed dimension was used to measure the amount of water applied, according to (Michael, 1978) as the following equation :

\section{Where:}

$$
\mathbf{Q}=\mathbf{C A} \sqrt{2 \mathrm{gh}}
$$

$\mathrm{Q}=$ discharge through orifice, $(1 / \mathrm{sec})$.

$\mathrm{C}=$ coefficient of discharge, $(0.61)$.

$A=$ cross-sectional area of the orifice, $\mathrm{cm}^{2}$.

$\mathrm{g}=$ acceleration due to gravity, $\mathrm{cm} / \mathrm{sec}^{2}\left(981 \mathrm{~cm} / \mathrm{sec}^{2}\right)$.

$\mathrm{h}=$ pressure head, causing discharge through the orifice, $\mathrm{cm}$.

\section{Water use efficiency (W.U.E):}

Applied irrigation water is used to describe the relationship between production and the amount of water applied. It was determined according to(Jensen 1983). The following equation was used as follow:

\section{W.U.E $=\overbrace{\text { Seasonal AIW ( } \mathrm{m}^{3} \text { water applied/fed.) }}$}

Soil analysis:

Fruits yield $(\mathbf{k g}) / \mathrm{fed}$.

Particle size distribution was conducted using the pipette method according to Klute (1986). Soil moisture constants were determined using the pressure membrane apparatus (Stackman 1966). Soil pH, electric conductivity (EC) and cationic and anionic compositions of the saturation extract of the soil were determined according to the standard methods described by Page et al. (1982).

\section{Plant analysis:}

Total nitrogen was determined by the micro-kjeldahl method according to Cottenie et al., (1982). Total phosphorus was determined in concentrated acid digest and measured using a spectrophotometer (Spectronic 20) to the method described by Murphy and Reily (1962). Total potassium content was determined in the acid digest using Atomic Absorption Spectrophotometer method for plant analysis according to method described by Jackson and Ulrish (1959) and Chapman and Pratt (1961). Total chlorophyll in fresh were determined using the methods described by Wettstein (1957). 


\section{Statistical analysis:}

Data were statistically analyzed according to the analysis of variance as described by Waller and Duncan (1969).

\section{RESULTS AND DISCUSSION}

\section{Soil water relations:}

Applied irrigation water:

Results in (Table, 4) showed that seasonal applied irrigation water to lettuce plants were less under drip irrigation as compared with surface irrigation in both seasons. Under conditions of surface irrigation, the highest seasonal applied irrigation water was that of $I_{2}$ and the lowest was that of $I_{1}$. Such result might be reasonable, since the exposed surface area under surface system provides high evaporation opportunity from the relatively wet rather than dry soil surface as in drip irrigation. Inanition, the high amount of water applied under surface system reflects the low system efficiency as compared with the drip system. The seasonal water use values were obtained from the sum of water for all irrigations per treatment, from November until January in each season. The obtained results were in harmony with those reported by Kucukyumuk et al. (2012) .

Table 4.Monthly and seasonal applied irrigation water to lettuce by the two irrigation system in 2013/14 and 2014/15 growing seasons.

\begin{tabular}{|c|c|c|c|c|c|c|c|c|}
\hline \multirow[b]{3}{*}{ Months } & \multicolumn{4}{|c|}{ Drip irrigation $\left(\mathrm{m}^{3} / \mathrm{fed}\right)$} & \multicolumn{4}{|c|}{ Surface irrigation $\left(m^{3} / \mathrm{fed}\right)$} \\
\hline & \multicolumn{2}{|c|}{$2013 / 14$} & \multicolumn{2}{|c|}{$2014 / 15$} & \multicolumn{2}{|c|}{$2013 / 14$} & \multicolumn{2}{|c|}{$2014 / 15$} \\
\hline & $l_{1}$ & $\mathbf{I}_{2}$ & $I_{1}$ & $\mathbf{I}_{2}$ & $I_{1}$ & $I_{2}$ & $I_{1}$ & $I_{2}$ \\
\hline November & 130.7 & 160.5 & 132.2 & 168.1 & 224.6 & 246.3 & 229.8 & 263.5 \\
\hline December & 339.0 & 433.3 & 329.0 & 440.0 & 389.3 & 555.5 & 399.4 & 584.2 \\
\hline January & 381.3 & 453.4 & 393.0 & 478.2 & 467.8 & 710.2 & 488.1 & 767.5 \\
\hline Total & 851 & 1047.2 & 854.2 & 1086.3 & 1081.7 & 1512.0 & 1117.3 & 1615.2 \\
\hline
\end{tabular}

$\mathrm{I}_{1}$ Irrigation when $\mathbf{5 0} \%$ of available soil moisture is depleted.

$\mathrm{I}_{2} \quad$ Irrigation when $25 \%$ of available soil moisture is depleted.

\section{Monthly applied irrigation water}

Results in Table (4) and Fig. (1) show that monthly applied water values began to raise during February then gradually increased to reach its maximum during January. Under drip system, maximum applied irrigation water values were affected by irrigation regimes. While under surface irrigation system, maximum applied irrigation water values were occurred also in June in the same seasons, respectively. In January the plants were fully developed thus the soil was subjected to greater loss of water in January compared with the other two months. In the two seasons, monthly water consumption started low when plants were small and increased gradually with increasing plant growth reaching a maximum in January mainly due to increased demand for water by plants .

The monthly water consumption took a rather similar trend. This result reveals that the monthly water consumptive use starts small because plant 
seedlings need less water at their initial growth stage. Therefore, soil moisture losses are mainly by evaporation form soil surface at that time. With the advance in plant age, transpiration increased and consequently monthly consumptive use increased as plant foliage developed. Soil moisture depletion in the advanced growth phase is due to evapotranspiration (ET); and daily water consumptive use reaches its peak at the end of the growing season as the crop reaches the harvest stage.
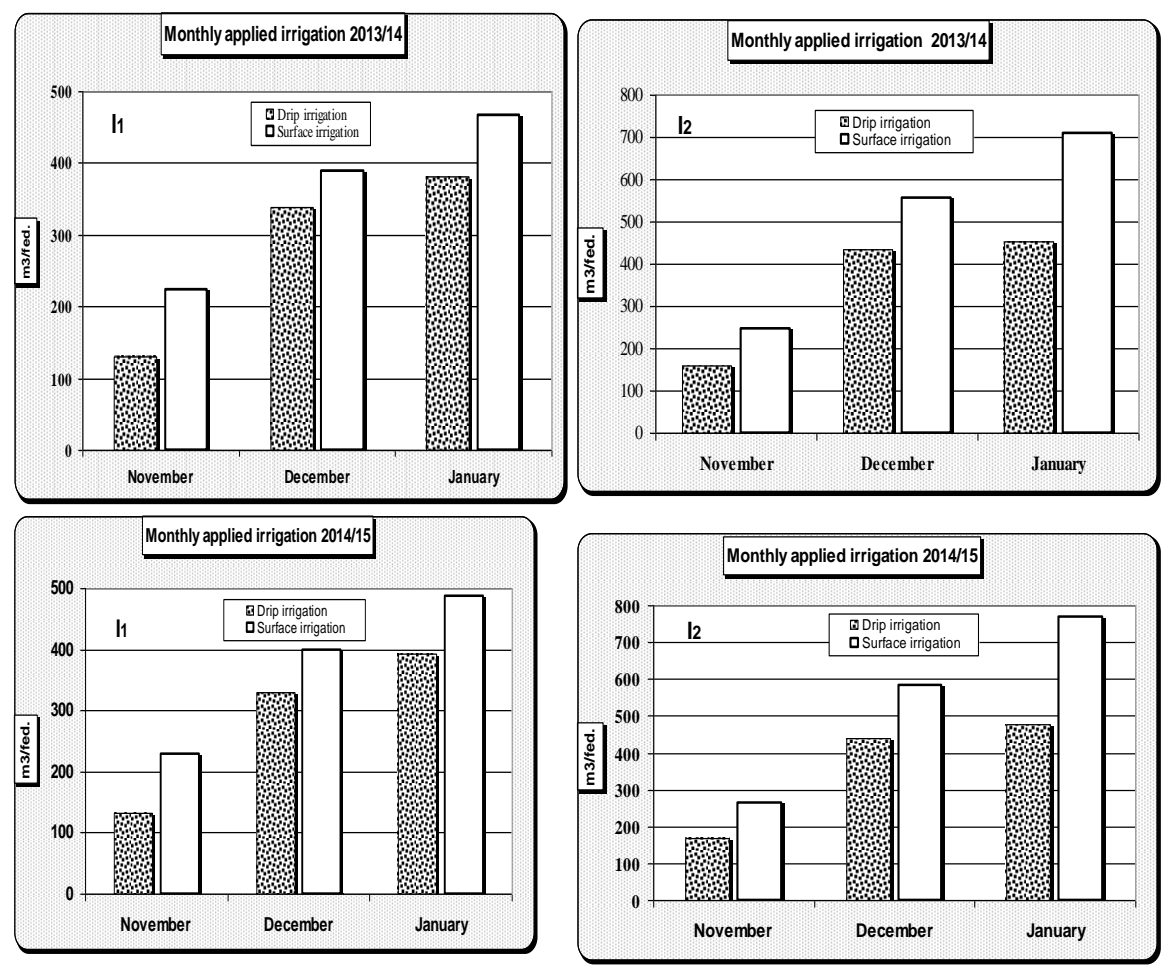

Fig.(1).Monthly applied irrigation water under surface and drip irrigation systems in $2013 / 14$ and $2014 / 15$ seasons.

$I_{1}$ Irrigation when $50 \%$ of available soil moisture is depleted.

$\mathrm{I}_{2}$ Irrigation when $\mathbf{2 5} \%$ of available soil moisture is depleted

Water use efficiency (W.U.E):

Water use efficiency represented the amount of yield produced for every cubic meter of water used by the crop. Results in current study indicated that, there was significant effect of the irrigation systems on W.U.E value (Fig. 2.). The obtained values were significantly different under drip irrigation system than under surface system in 2013/14 and 2014/15 seasons,. The values of Water use efficiency for lettuce as affected by available soil moisture depletion The dry irrigation $\mathrm{l}_{1}$ gave the highest water use efficiency. While under medium 
irrigation i.e., $I_{2}$ were lower. Fertilized treatments gave greater water use efficiency, than the unfertilized ones and ammonium sulphate gave the highest efficiency both seasons. There was an interaction between fertilizer treatments and moisture regimes : the ammonium sulphate and ammonium nitrate were similar under the dry regime season 2013/14 under surface irrigation.
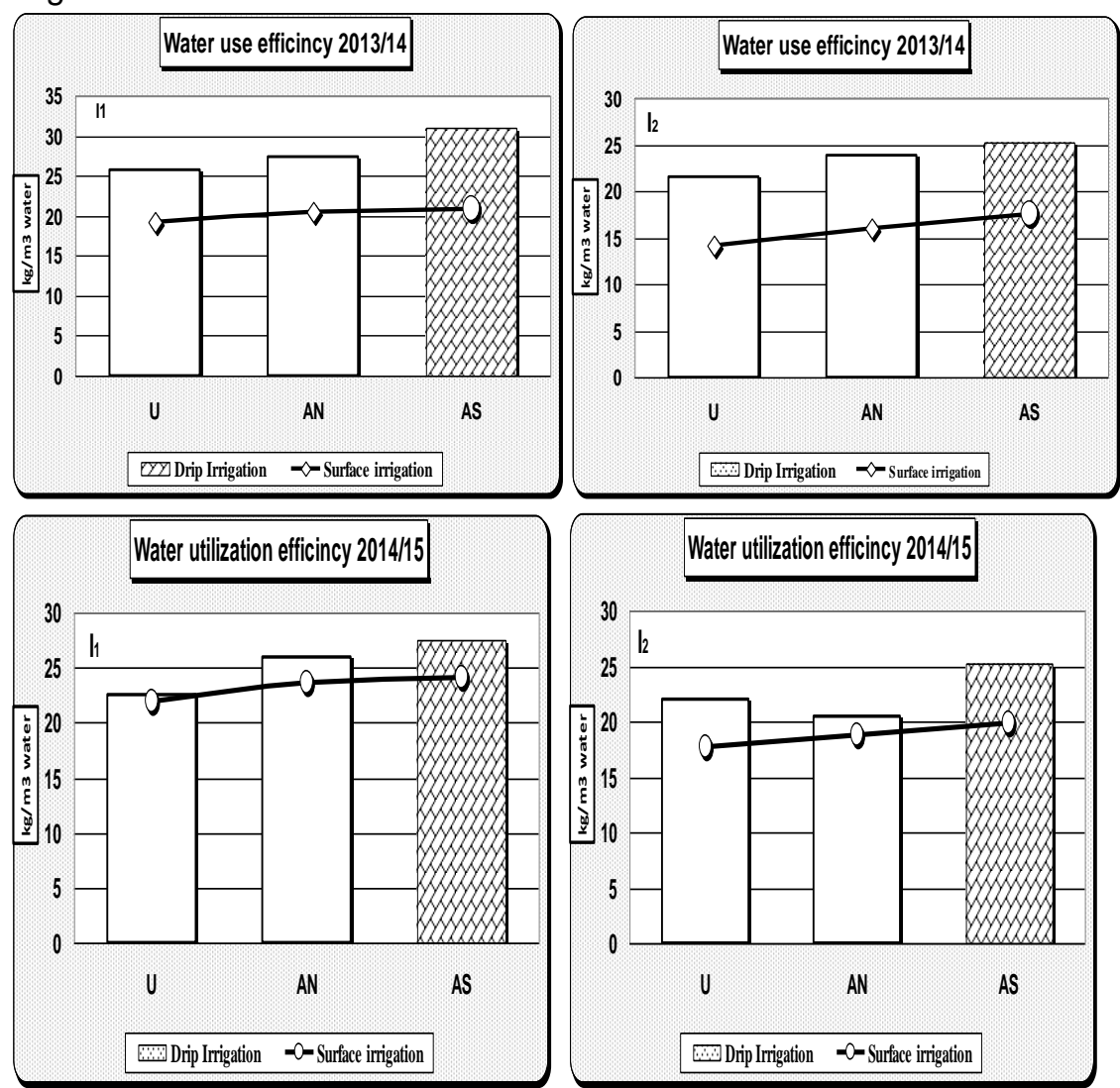

Fig. (2).Effect of irrigation systems, available soil moisture depletion and nitrogen fertilization on Water utilization efficiency $\left(\mathrm{kg} / \mathrm{m}^{3}\right.$ water) during 2013/14 and 2014/15. seasons

$I_{1}$ Irrigation when $50 \%$ of available soil moisture is depleted.

$I_{2}$ Irrigation when $25 \%$ of available soil moisture is depleted.

U urea $(46 \% \mathrm{~N})$.. - AN ammonium nitrate, $(33.5 \% \mathrm{~N})$.

AS ammonium sulphate $(20.6 \% \mathrm{~N})$.

2. Growth parameters:

\section{Plant height}

The main effects of irrigation system show that drip irrigation gave the higher value of plant height than surface irrigation. Excess water seemed to have encouraged plant growth in terms of height. The main effect of fertilizers show that the highest plant height was given by ammonium sulphate and the lowest was by urea. While with ammonium nitrate gave intermediate values. Shafshak and Abo Sedera (1990) and Eissa and Header 
(1991) reported that height of lettuce was greater with ammonium sulphate than ammonium nitrate and some other sources.

Table ( 5 ): Effect of irrigation systems, available soil moisture depletion and nitrogen fertilization on plant height $(\mathrm{cm})$ during 2013/14 and 2014/15.

\begin{tabular}{|c|c|c|c|c|c|c|c|c|c|}
\hline \multirow{3}{*}{\multicolumn{2}{|c|}{\begin{tabular}{|l|}
$\begin{array}{l}\text { Irrigation } \\
\text { treatment }\end{array}$ \\
Irrigation \\
systems
\end{tabular}}} & \multicolumn{8}{|c|}{ Nitrogen fertilization } \\
\hline & & \multicolumn{4}{|c|}{ Season $2013 / 2014$} & \multicolumn{4}{|c|}{ Season 2014/2015 } \\
\hline & & $\mathbf{U}$ & AN & AS & $\begin{array}{l}\text { Mean } \\
\mathrm{A} \times \mathrm{B}\end{array}$ & $\mathbf{U}$ & AN & AS & $\begin{array}{l}\text { Mean } \\
A \times B\end{array}$ \\
\hline Drip & $\mathrm{I}_{1}$ & $36.0 f$ & 42.0ce & $45.0 b$ & $41.0 \mathrm{~B}$ & 38.0ef & $42.7 c$ & $44.3 \mathrm{bc}$ & $41.7 \mathrm{~B}$ \\
\hline Irrigation & $\mathrm{I}_{2}$ & $41.7 \mathrm{de}$ & $44.3 \mathrm{bc}$ & $47.3 a$ & $44.4 \mathrm{~A}$ & 39.7de & $43.3 \mathrm{bc}$ & $49.7 a$ & $44.2 \mathrm{~A}$ \\
\hline \multicolumn{2}{|c|}{ Mean $(\mathrm{A} \times \mathrm{C})$} & $38.8 \mathrm{D}$ & $43.2 B$ & $46.2 \mathrm{~A}$ & $42.7 \mathrm{~A}$ & $38.8 \mathrm{D}$ & $43.0 \mathrm{C}$ & $47.0 \mathrm{~A}$ & $42.9 \mathrm{~A}$ \\
\hline Surface & $\mathrm{I}_{1}$ & $36.0 f$ & $41.7 \mathrm{de}$ & $44.0 b-d$ & $40.6 \mathrm{~B}$ & $37.0 f$ & $41.7 \mathrm{~cd}$ & $43.7 \mathrm{bc}$ & $40.8 \mathrm{~B}$ \\
\hline irrigation & $\mathrm{I}_{2}$ & $36.3 f$ & $41.0 \mathrm{e}$ & $44.3 \mathrm{bc}$ & $40.6 \mathrm{~B}$ & $36.3 f$ & $43.0 \mathrm{c}$ & $46.0 \mathrm{~b}$ & $41.8 \mathrm{~B}$ \\
\hline \multicolumn{2}{|c|}{ Mean $(\mathrm{A} \times \mathrm{C})$} & $36.2 \mathrm{E}$ & $41.3 \mathrm{C}$ & $44.2 \mathrm{~B}$ & $42.5 \mathrm{~A}$ & $36.7 \mathrm{E}$ & $42.3 \mathrm{C}$ & $44.8 \mathrm{~B}$ & \\
\hline Grand me & (C) & $37.5 \mathrm{C}$ & $42.3 \mathrm{~B}$ & $45.2 \mathrm{~A}$ & & $37.8 \mathrm{C}$ & $42.7 \mathrm{~B}$ & $45.9 \mathrm{~A}$ & \\
\hline \multicolumn{10}{|c|}{ Means of irrigation treatments } \\
\hline & $\mathrm{l}_{1}$ & $36.0 \mathrm{D}$ & $41.8 \mathrm{~B}$ & $44.5 \mathrm{~A}$ & $40.8 \mathrm{~B}$ & $37.5 \mathrm{C}$ & $42.2 \mathrm{~B}$ & $44.0 \mathrm{~B}$ & $41.2 B$ \\
\hline$(B \times C)$ & $\mathbf{I}_{2}$ & $39.0 \mathrm{C}$ & $42.7 \mathrm{~B}$ & $45.8 \mathrm{~A}$ & $42.5 \mathrm{~A}$ & $38.0 \mathrm{C}$ & $43.2 \mathrm{~B}$ & $47.8 \mathrm{~A}$ & 43.0A \\
\hline
\end{tabular}

Notes : $I_{1}$ : Irrigation when $50 \%$ of available soil moisture is depleted.

$I_{2}$ : Irrigation when $25 \%$ of available soil moisture is depleted.

U : urea $(46 \% \mathrm{~N})$.

AN : ammonium nitrate $(33.5 \% \mathrm{~N})$

AS : ammonium sulphate $(20.6 \% \mathrm{~N})$

\section{Number of leaves / plant}

The main effects of irrigation system show that drip irrigation gave the highest value of number of leaves/plant followed by surface irrigation (Table 6). Under drip irrigation shows that $I_{2}$ medium soil moisture regime gave the highest number of leaves of plant followed by $I_{1}$ dry while under surface irrigation system, in both seasons the two regimes of $I_{1}$ and $I_{2}$ were similar, without significant difference between them. The main effect of fertilizer treatments shows that the highest number of leaves among fertilized treatments was given by ammonium sulphate followed by ammonium nitrate and the least was given by urea. There were interactions caused by irrigation system on fertilizer treatments. ammonium sulphate, ammonium nitrate and urea were similar in the some cases $I_{2}$ the medium regime under surface irrigation system . 
Table ( 6 ): Effect of irrigation systems, available soil moisture depletion and nitrogen fertilization on number of leaves/ plant during 2013/14 and 2014/15.

\begin{tabular}{|c|c|c|c|c|c|c|c|c|c|}
\hline \multirow{3}{*}{\multicolumn{2}{|c|}{\begin{tabular}{|l} 
Irrigation \\
treatment \\
Irrigation \\
systems
\end{tabular}}} & \multicolumn{8}{|c|}{ Nitrogen fertilization } \\
\hline & & \multicolumn{4}{|c|}{ Season 2013/2014 } & \multicolumn{4}{|c|}{ Season 2014/2015 } \\
\hline & & \multirow{2}{*}{$\frac{\mathbf{U}}{30.3 \mathrm{~g}}$} & \multirow{2}{*}{\begin{tabular}{|c|} 
AN \\
$32.7 \mathrm{de}$
\end{tabular}} & \multirow{2}{*}{\begin{tabular}{|c|} 
AS \\
$34.0 \mathrm{~d}$
\end{tabular}} & \multirow{2}{*}{$\begin{array}{l}\text { Mean } \\
\mathrm{A} \times \mathrm{B} \\
32.3 \mathrm{~B}\end{array}$} & \multirow{2}{*}{$\frac{\mathbf{U}}{30.3 \mathrm{~g}}$} & \multirow{2}{*}{\begin{tabular}{|c|} 
AN \\
$32.3 \mathrm{ef}$
\end{tabular}} & \multirow{2}{*}{\begin{tabular}{|c|} 
AS \\
$34.0 \mathrm{~d}$
\end{tabular}} & \multirow{2}{*}{\begin{tabular}{|c|} 
Mean \\
A x B \\
$32.2 B$ \\
\end{tabular}} \\
\hline Drip & $\mathrm{I}_{1}$ & & & & & & & & \\
\hline Irrigation & $\mathrm{I}_{2}$ & $41.0 \mathrm{c}$ & $44.7 \mathrm{~b}$ & $49.0 \mathrm{a}$ & $44.9 \mathrm{~A}$ & $41.0 \mathrm{c}$ & $42.3 \mathrm{~b}$ & $44.7 \mathrm{a}$ & $42.7 \mathrm{~A}$ \\
\hline \multicolumn{2}{|c|}{ Mean $(\mathrm{A} \times \mathrm{C})$} & $35.7 \mathrm{C}$ & $38.7 \mathrm{~B}$ & $41.5 \mathrm{~A}$ & $38.6 \mathrm{~A}$ & $35.7 \mathrm{C}$ & $37.3 \mathrm{~B}$ & 39.3A & $37.4 \mathrm{~A}$ \\
\hline & $\mathrm{l}_{1}$ & $31.0 \mathrm{fg}$ & 32.3ef & 33.0de & $32.1 \mathrm{~B}$ & 32.3ef & 33.0de & 33.3de & $32.9 \mathrm{~B}$ \\
\hline & $\mathrm{I}_{2}$ & 32.0ef & 32.3ef & 32.3ef & $32.2 \mathrm{~B}$ & $31.3 \mathrm{fg}$ & 33.0de & $34.0 \mathrm{~d}$ & $32.8 \mathrm{~B}$ \\
\hline \multicolumn{2}{|c|}{ Mean (A X C) } & $31.5 \mathrm{E}$ & $32.2 \mathrm{DE}$ & 32.7D & $32.2 \mathrm{~B}$ & $31.8 \mathrm{E}$ & 33.0D & 33.7D & $32.8 \mathrm{~B}$ \\
\hline Grand $\mathrm{me}$ & $n(C)$ & $33.6 \mathrm{C}$ & $35.5 \mathrm{~B}$ & $37.1 \mathrm{~A}$ & & $33.7 \mathrm{C}$ & $35.2 \mathrm{~B}$ & $36.5 \mathrm{~A}$ & \\
\hline \multicolumn{10}{|c|}{ Means of irrigation treatments } \\
\hline Mean & $l_{1}$ & $30.7 \mathrm{~F}$ & $32.5 \mathrm{E}$ & $33.5 \mathrm{D}$ & $32.2 \mathrm{~B}$ & $31.3 \mathrm{~F}$ & 32.7E & 33.7D & $32.6 \mathrm{~B}$ \\
\hline$(B \times C)$ & $\mathrm{I}_{2}$ & $36.5 \mathrm{C}$ & $38.5 \mathrm{~B}$ & $40.7 \mathrm{~A}$ & $38.6 \mathrm{~A}$ & $36.2 \mathrm{C}$ & 37.7B & $39.3 A$ & $37.7 \mathrm{~A}$ \\
\hline
\end{tabular}

Notes : $l_{1}$ : Irrigation when $50 \%$ of available soil moisture is depleted.

$I_{2}$ : Irrigation when $25 \%$ of available soil moisture is depleted.

U : urea $(46 \% \mathrm{~N})$.

AN : ammonium nitrate $(33.5 \% \mathrm{~N})$.

AS : ammonium sulphate $(20.6 \% \mathrm{~N})$.

\section{Fresh weight /plant}

The main effect of irrigation system indicates a superiority of drip irrigation over surface irrigation in the first season, while surface irrigation showed superiority over drip irrigation in the second season (Table 7). Under drip irrigation soil moisture regimes results show that the greatest fresh weight of plant was given by $I_{2}$ and the lowest was that of the $I_{1}$. There was an interactive effect in season 1 for the two regimes of $I_{1}$ and $I_{2}$ were similar in their effect under conditions of ammonium sulphate fertilizer application.

The main effects of fertilizers show that the highest weight among fertilized treatments was that of AS, and the lowest was that of $U$. The results of the current study agree with those reported by Meleha (1992) who compared in a pot experiment ammonium sulphate with urea on barley under three water regimes ( of $100 \%, 75 \%$ and $50 \%$ of field capacity) and found superiority of ammonium sulphate regarding plant growth only under the wet regime (of $100 \%$ field capacity) with no significant defferences between the two sources under other regimes. Shafshak and Abo Sedera (1990) reported also superiority of ammonium sulphate over ammonium nitrate for lettuce. 
Table ( 7 ): Effect of irrigation systems, available soil moisture depletion and nitrogen fertilization on plant fresh weight ( $\mathrm{g} / \mathrm{plant}$ ) during 2013/14 and 2014/15 .

\begin{tabular}{|c|c|c|c|c|c|c|c|c|c|}
\hline \multirow{3}{*}{\multicolumn{2}{|c|}{\begin{tabular}{|l|}
$\begin{array}{l}\text { Irrigation } \\
\text { treatment }\end{array}$ \\
Irrigation \\
systems
\end{tabular}}} & \multicolumn{8}{|c|}{ Nitrogen fertilization } \\
\hline & & \multicolumn{4}{|c|}{ Season $2013 / 2014$} & \multicolumn{4}{|c|}{ Season 2014/2015 } \\
\hline & & $\mathbf{U}$ & AN & AS & Mean & $\mathbf{U}$ & AN & AS & Mean \\
\hline Drip & $l_{1}$ & 498.7gh & $556.7 d$ & $626.7 a$ & $560.7 \mathrm{C}$ & $458.0 \mathrm{j}$ & $529.3 i$ & $559.3 \mathrm{~h}$ & $515.6 \mathrm{C}$ \\
\hline Irrigation & $\mathrm{I}_{2}$ & 536.0 ef & $593.3 b$ & $629.3 a$ & $586.2 \mathrm{~A}$ & $570.0 \mathrm{gh}$ & $616.7 f$ & $652.7 d$ & $613.1 \mathrm{~B}$ \\
\hline \multicolumn{2}{|c|}{ Mean (A X C) } & $517.3 \mathrm{E}$ & $575.0 \mathrm{C}$ & $628.0 \mathrm{~A}$ & $573.4 \mathrm{~A}$ & 514.0F & $573.0 \mathrm{E}$ & $606.0 \mathrm{D}$ & 564.3B \\
\hline Surface & $\mathrm{I}_{1}$ & 495.0h & $526.7 f$ & $539.3 e$ & 520.3D & $582.0 \mathrm{~g}$ & 630.0ef & $640.7 \mathrm{de}$ & $617.6 B$ \\
\hline irrigation & $\mathrm{I}_{2}$ & $510.0 \mathrm{~g}$ & $576.7 \mathrm{c}$ & $630.0 a$ & $572.2 \mathrm{~B}$ & $680.0 \mathrm{c}$ & $722.0 \mathrm{~b}$ & $762.0 \mathrm{a}$ & $721.3 \mathrm{~A}$ \\
\hline \multicolumn{2}{|c|}{ Mean $(\mathrm{A} \times \mathrm{C})$} & $502.5 \mathrm{~F}$ & 551.7D & 584.7B & 546.3B & $631.0 \mathrm{C}$ & $676.0 \mathrm{~B}$ & $701.3 \mathrm{~A}$ & $669.4 \mathrm{~A}$ \\
\hline \multicolumn{2}{|c|}{ Grand mean (C) } & $509.9 \mathrm{C}$ & 563.3B & 606.3A & & $572.5 \mathrm{C}$ & 624.5B & $653.7 \mathrm{~A}$ & \\
\hline \multicolumn{10}{|c|}{ Means of irrigation treatments } \\
\hline $\begin{array}{l}\text { Mean } \\
(B \times C) \\
\end{array}$ & $\begin{array}{l}\mathrm{l}_{1} \\
\mathrm{l}_{2}\end{array}$ & \begin{tabular}{|l|}
$496.8 \mathrm{E}$ \\
$523.0 \mathrm{D}$
\end{tabular} & \begin{tabular}{|l|}
$541.7 \mathrm{C}$ \\
$585.0 \mathrm{~B}$
\end{tabular} & $\begin{array}{l}583.0 B \\
629.7 A\end{array}$ & $\begin{array}{l}540.5 B \\
579.2 A\end{array}$ & $\begin{array}{l}520.0 \mathrm{~F} \\
625.0 \mathrm{C}\end{array}$ & $\begin{array}{l}579.7 \mathrm{E} \\
669.3 \mathrm{~B}\end{array}$ & $\begin{array}{l}\text { 600.0D } \\
707.3 \mathrm{~A} \\
\end{array}$ & \begin{tabular}{|l|}
$566.6 \mathrm{~B}$ \\
$667.2 \mathrm{~A}$
\end{tabular} \\
\hline Notes : $I_{1}$ & & 4 mon & $50 \%$ of $a$ & vailable & & ture is de & $\begin{array}{l}\text { epleted. } \\
\text { epleted. }\end{array}$ & & \\
\hline
\end{tabular}

\section{Yield per feddan}

Yield per feddan in the current study was presented in. Table (8) The main effect of irrigation system indicated a superiority of drip irrigation over surface irrigation in the first season, while surface irrigation superiority over drip irrigation in the second season. Under drip irrigation soil moisture regimes the greatest yield was given by $I_{2}$ and the lowest was that of the $I_{1}$. However, there were interactive effect particularly in season 1 : superiority of the $I_{2}$ medium moisture regime over the $I_{1}$ dry regime, under $N$ sources but under ammonium sulphate fertilization were alike. While in the second season, $I_{1}$ and $I_{2}$ were similar in their effect under conditions of ammonium nitrate .

The main effect of fertilizer treatments showed that the highest yield among the fertilized treatments was given by ammonium sulphate followed by ammonium nitrate; and the least was given by urea. However, there were interactions, under drip irrigation, ammonium nitrate resembled urea. While, ammonium sulphate and ammonium nitrate were similar in effect under conditions of surface irrigation in the second season. Shafshak and AboSedera (1990) reported superiority of ammonium sulphate over ammonium nitrate in growing the leafy vegetable plant of spinach . Khalil et al (1985) on spinach, found that the maximum growth rate and total yield were obtained by short-interval irrigations (irrigation upon depletion of $25 \%$ of available soil moisture). 
Table ( 8 ): Effect of irrigation systems, available soil moisture depletion and nitrogen fertilization on yield of fresh matter (ton/fed.) during 2013/14 and 2014/15

\begin{tabular}{|c|c|c|c|c|c|c|c|c|c|}
\hline \multirow{3}{*}{\multicolumn{2}{|c|}{\begin{tabular}{|l|} 
Irrigation \\
treatment \\
Irrigation \\
systems
\end{tabular}}} & \multicolumn{8}{|c|}{$\begin{array}{c}\text { Nitrogen fertilization } \\
\end{array}$} \\
\hline & & \multicolumn{4}{|c|}{ Season $2013 / 2014$} & \multicolumn{4}{|c|}{ Season $2014 / 2015$} \\
\hline & & $\mathbf{U}$ & AN & AS & Mean & $\mathbf{U}$ & AN & AS & Mean \\
\hline \begin{tabular}{|l|} 
Drip \\
Irrigation
\end{tabular} & $\begin{array}{l}\mid \mathrm{I}_{1} \\
\mathrm{I}_{2}\end{array}$ & \begin{tabular}{|l}
$20.94 f$ \\
$22.51 \mathrm{de}$
\end{tabular} & & \begin{tabular}{|l|}
$26.32 a$ \\
$26.43 a$
\end{tabular} & & & $\left|\begin{array}{l}22.23 f \\
22.23 f\end{array}\right|$ & \begin{tabular}{|l|}
$23.49 \mathrm{ef}$ \\
$27.41 \mathrm{~cd}$
\end{tabular} & \\
\hline Mean $(A X$ & X C) & $21.73 \mathrm{D}$ & 24. & $26.38 \mathrm{~A}$ & & & & & \\
\hline $\begin{array}{l}\text { Surface } \\
\text { irrigation }\end{array}$ & $\mid \begin{array}{l}\mathrm{I}_{1} \\
\mathrm{I}_{2}\end{array}$ & & & & & & & & \\
\hline Mean $(A X$ & X C) & $21.10 \mathrm{D}$ & $23.14 \mathrm{C}$ & $24.56 \mathrm{~B}$ & 22.93B & 26.50B & $28.39 \mathrm{~A}$ & $29.46 \mathrm{~A}$ & $28.12 \mathrm{~A}$ \\
\hline $\begin{array}{l}\text { Grand } \mathrm{m} \\
\text { (C) }\end{array}$ & & $21.42 \mathrm{C}$ & 23.64B & $25.47 \mathrm{~A}$ & & & $\mid<.0$ & $27.45 \mathrm{~A}$ & \\
\hline
\end{tabular}

Means of irrigation treatments

\begin{tabular}{|l|l|l|l|l|l|l|l|l|l|}
\hline Mean & $\mathrm{I}_{1}$ & $20.87 \mathrm{D}$ & $22.75 \mathrm{C}$ & $24.49 \mathrm{~B}$ & $22.70 \mathrm{~B}$ & $21.84 \mathrm{D}$ & $24.35 \mathrm{C}$ & $25.20 \mathrm{C}$ & $23.80 \mathrm{~B}$ \\
\hline
\end{tabular}

\begin{tabular}{lll|l|l|l|l|l|l|l|l|l|l|l|}
$(\mathrm{B} \times \mathrm{C})$ & $\mathrm{I}_{2}$ & $21.97 \mathrm{C}$ & $24.54 \mathrm{~B}$ & $26.45 \mathrm{~A}$ & $24.32 \mathrm{~A}$ & $26.25 \mathrm{~B}$ & $26.28 \mathrm{~B}$ & $29.71 \mathrm{~A}$ & $28.12 \mathrm{~A}$ \\
\hline
\end{tabular}

Notes : $l_{1}$ : Irrigation when $50 \%$ of available soil moisture is depleted.

$I_{2}$ : Irrigation when $25 \%$ of available soil moisture is depleted.

$U$ : urea $(46 \% N)$.

AN : ammonium nitrate $(33.5 \% \mathrm{~N})$.

AS : ammonium sulphate $(20.6 \% \mathrm{~N})$.

\section{Chemical composition:}

\section{Nitrogen uptake}

The main effect of irrigation system and moisture regime treatment shows that the drip irrigation system gave the highest $\mathrm{N}$-uptake followed by surface irrigation (Table 9). Under drip irrigation soil moisture regimes, the greatest $\mathrm{N}$-uptake was given by $\mathrm{I}_{2}$ and the lowest was that of the $I_{1}$. However, there were interactions particularly in season 1 : superiority of the $I_{1}$ dry moisture regime over the $\mathrm{I}_{2}$ medium regime was particularly apparent, under ammonium sulphate fertilization. Increased soil moisture may have probably enhanced ammonification of soil organic $\mathrm{N}$ as reported by (Bremner 1965).

The main effect of fertilizer treatments shows that the highest uptake of $\mathrm{N}$ among the fertilized treatments was given by ammonium sulphate followed by ammonium nitrate and the least was that given by urea. There were interactions caused by irrigation system on fertilizer treatments superiority of the, ammonium nitrate over the ammonium sulphate under drip irrigation system $\mathrm{I}_{2}$ in the second season. Dry conditions decreased uptake of $\mathrm{N}$ in soil since it decreased plant growth. The above results assert the importance having soil moisture niether too high nor too low in order to obtained high $\mathrm{N}$ uptake.Dry conditions decreased uptake of $\mathrm{N}$ in soil since it decreased plant growth Eissa and Header (1991) reported little differences in $\mathbf{N}$ uptake under low moisture contents . Meleha (1992), reported that keeping soil at $100 \%$ of its water holding capacity resulted in greater $\mathrm{N}$ uptake by barley as compared with $75 \%$ or $50 \%$ water holding capacity and that ammonium sulphate gave greater $\mid \mathrm{N}$ uptake than urea. 
Table ( 9 ): Effect of irrigation systems, available soil moisture depletion and nitrogen fertilization on uptake ( $\mathrm{N} \mathrm{mg} /$ plant) during 2013/14 and 2014/15.

\begin{tabular}{|c|c|c|c|c|c|c|c|c|c|}
\hline \multirow{3}{*}{\multicolumn{2}{|c|}{\begin{tabular}{|l} 
Irrigation \\
treatment \\
Irrigation \\
systems
\end{tabular}}} & \multicolumn{8}{|c|}{ Nitrogen fertilization } \\
\hline & & \multicolumn{4}{|c|}{ Season $2013 / 2014$} & \multicolumn{4}{|c|}{ Season 2014/2015 } \\
\hline & & \multirow{3}{*}{\begin{tabular}{|c|}
$\mathbf{U}$ \\
$1588 g$ \\
$1672 f$ \\
\end{tabular}} & \multirow{2}{*}{\begin{tabular}{c|} 
AN \\
$1639 f$
\end{tabular}} & \multirow{2}{*}{\begin{tabular}{|c|} 
AS \\
$1911 d$ \\
\end{tabular}} & \multirow{2}{*}{$\begin{array}{c}\text { Mean } \\
1713 \mathrm{C}\end{array}$} & \multirow{2}{*}{$\begin{array}{c}\mathbf{U} \\
1737 f\end{array}$} & \multirow{2}{*}{$\begin{array}{c}\text { AN } \\
1861 d\end{array}$} & \multirow{2}{*}{\begin{tabular}{|c} 
AS \\
$2120 \mathrm{~b}$
\end{tabular}} & \multirow{2}{*}{$\begin{array}{c}\text { Mean } \\
1906 \mathrm{~B}\end{array}$} \\
\hline \begin{tabular}{|l|l} 
Drip & \\
\end{tabular} & $\mathrm{I}_{1}$ & & & & & & & & \\
\hline Irrigation & $\mathrm{I}_{2}$ & & 1932d & $2240 a$ & $1948 \mathrm{~A}$ & $1852 d$ & $2263 a$ & $2138 b$ & $2084 \mathrm{~A}$ \\
\hline \multicolumn{2}{|c|}{ Mean $(\mathrm{A} X \mathrm{C})$} & 1630D & $1786 \mathrm{C}$ & $2076 \mathrm{~B}$ & $1830 \mathrm{~A}$ & 1795D & $2062 B$ & $2129 A$ & $1995 \mathrm{~A}$ \\
\hline Surface & $\mathrm{l}_{1}$ & $1438 \mathrm{i}$ & $1584 \mathrm{~g}$ & $2164 b$ & $1729 \mathrm{C}$ & $1242 \mathrm{j}$ & $1521 \mathrm{~h}$ & $1810 e$ & 1524D \\
\hline irrigation & $\mathrm{I}_{2}$ & $1474 h$ & $1717 \mathrm{e}$ & $2054 c$ & 1748B & $1368 \mathrm{i}$ & $1583 g$ & $2009 c$ & $1653 C$ \\
\hline \multicolumn{2}{|c|}{ Mean $(A \times C)$} & $1456 \mathrm{E}$ & 1650D & 2019A & $1739 \mathrm{~B}$ & $1305 \mathrm{~F}$ & $1552 \mathrm{E}$ & $1910 \mathrm{C}$ & $1589 \mathrm{~B}$ \\
\hline \multicolumn{2}{|c|}{ Grand mean (C) } & $1543 C$ & 1718B & $2092 A$ & & $1550 C$ & & & \\
\hline \multicolumn{10}{|c|}{ Means of irrigation treatments } \\
\hline Mean & $I_{1}$ & $1513 \mathrm{~F}$ & $1611 \mathrm{D}$ & $2037 \mathrm{~B}$ & 1721B & $1490 \mathrm{~F}$ & 1691D & 1965B & 1715B \\
\hline$(B \times C)$ & $\mathrm{I}_{2}$ & 1573E & $1825 \mathrm{C}$ & $2147 A$ & $1848 \mathrm{~A}$ & $1610 \mathrm{E}$ & $1923 C$ & $2073 A$ & $1869 \mathrm{~A}$ \\
\hline \multicolumn{10}{|c|}{ 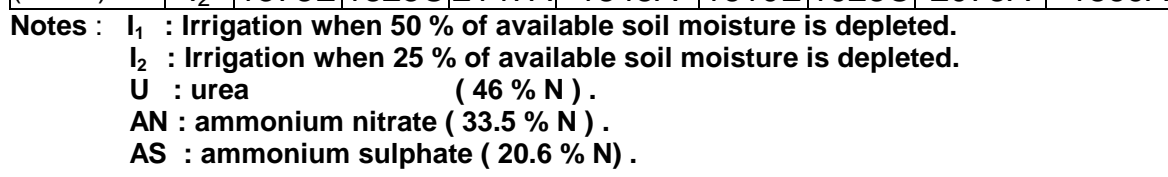 } \\
\hline
\end{tabular}

Phosphorus uptake.

The effects of irrigation treatments and fertilizer $\mathrm{N}$ sources on phosphorus uptake are shown in Table 10. Main effect of irrigation system and soil moisture shows significant difference between irrigation treatments a superiority of drip irrigation over surface irrigation . Under drip irrigation soil moisture regimes $P$ uptake given by $I_{2}$ was higher than that of the $I_{1}$. However, there were interactions superiority of the $I_{2}$ medium moisture regime over the $I_{1}$ dry regime but under ammonium sulphate, in second season found $I_{1}$ and $I_{2}$ were similar under drip irrigation system . While in the first season, $I_{1}$ and $l_{2}$ were similar in their effect under conditions of ammonium sulpht and urea under surface irrigation system .

The main effect of fertilizer treatments shows that ammonium sulphate gave the highest $\mathrm{P}$ uptake followed by ammonium nitrate ,then urea. However, such a pattern of main effect did not occur under any of the two moisture regimes exhibiting a clear case of moisture /fertilizer interaction .Under the medium regime $\mathrm{I}_{2}$, ammonium nitrate surpassed ammonium sulphate under drip irrigation system in second season . 
Table (10): Effect of irrigation systems, available soil moisture depletion and nitrogen fertilization on uptake $P$ mg/plant during 2013/14 and 2014/15.

\begin{tabular}{|c|c|c|c|c|c|c|c|c|c|}
\hline \multirow{3}{*}{\multicolumn{2}{|c|}{\begin{tabular}{|l} 
Irrigation \\
treatment \\
Irrigation \\
systems
\end{tabular}}} & \multicolumn{8}{|c|}{ Nitrogen fertilization } \\
\hline & & \multicolumn{4}{|c|}{ Season $2013 / 2014$} & \multicolumn{4}{|c|}{ Season $2014 / 2015$} \\
\hline & & $\mathbf{U}$ & AN & AS & Mean & $\mathbf{U}$ & AN & AS & Mean \\
\hline Drip & $\mathrm{I}_{1}$ & $185.7 \mathrm{fg}$ & 204.6ef & $244.5 \mathrm{~cd}$ & $211.6 C$ & $201.9 \mathrm{fg}$ & 230.9de & $273.1 \mathrm{bc}$ & 235.3B \\
\hline Irrigation & $\mathrm{I}_{2}$ & $212.3 e$ & $258.2 b c$ & $292.9 a$ & $254.5 \mathrm{~A}$ & $234.4 d$ & $303.9 a$ & $279.8 b$ & 272.7A \\
\hline \multicolumn{2}{|c|}{ Mean (A X C) } & 199.0D & 231.4B & 268.7A & $233.1 \mathrm{~A}$ & $218.1 \mathrm{C}$ & $267.4 \mathrm{~A}$ & $276.5 \mathrm{~A}$ & 254.0A \\
\hline Surface & $\mathrm{l}_{1}$ & $169.1 \mathrm{~g}$ & 199.7ef & $278.0 \mathrm{ab}$ & $215.6 \mathrm{C}$ & $145.3 \mathrm{i}$ & $190.8 \mathrm{~g}$ & $233.4 d$ & 189.8D \\
\hline irrigation & $\mathrm{I}_{2}$ & $184.5 \mathrm{fg}$ & $231.9 d$ & $268.7 \mathrm{~b}$ & $228.4 \mathrm{~B}$ & 173.3h & 214.1ef & $259.3 c$ & 215.5C \\
\hline \multicolumn{2}{|c|}{ Mean $(\mathrm{A} \times \mathrm{C})$} & $176.8 \mathrm{E}$ & $215.8 C$ & $273.4 \mathrm{~A}$ & $222.0 \mathrm{~B}$ & 159.3E & 202.4D & 246.4B & 202.7B \\
\hline Grand me & $(\mathrm{C})$ & $187.9 \mathrm{C}$ & 223.6B & $271.1 \mathrm{~A}$ & & $188.7 \mathrm{C}$ & 234.9B & $261.4 \mathrm{~A}$ & \\
\hline \multicolumn{10}{|c|}{ Means of irrigation treatments } \\
\hline Mean & $\mathrm{l}_{1}$ & $177.4 \mathrm{E}$ & 202.1D & $261.3 \mathrm{~B}$ & $213.6 \mathrm{~B}$ & 173.6D & $210.9 \mathrm{C}$ & 253.3B & 212.6B \\
\hline$(B \times C)$ & $\mathrm{I}_{2}$ & 198.4D & $245.1 \mathrm{C}$ & $280.8 \mathrm{~A}$ & $241.4 \mathrm{~A}$ & $203.8 C$ & 259.0AB & & \\
\hline \multicolumn{10}{|c|}{$\begin{array}{l}\text { Notes : } I_{1}: \text { Irrigation when } 50 \% \text { of available soil moisture is depleted. } \\
I_{2}: \text { Irrigation when } 25 \% \text { of available soil moisture is depleted. } \\
U \text { : urea } \quad(46 \% \mathrm{~N}) \text {. } \\
\text { AN : ammonium nitrate }(33.5 \% \mathrm{~N}) \\
\text { AS : ammonium sulphate }(20.6 \% \mathrm{~N})\end{array}$} \\
\hline
\end{tabular}

\section{Potassium uptake}

In (Table 11) results indicated that, there was significant effect for the irrigation systems on $\mathrm{K}$ uptake values. Under drip irrigation soil moisture regimes, the greatest $\mathrm{K}$ uptake was given by $\mathrm{I}_{2}$ and the lowest was that of the $\mathrm{I}_{1}$. There was an interaction under conditions of ammonium sulphate and urea, $l_{1}$ and $l_{2}$ were similar in season 1 under surface irrigation system.

The main effect of fertilizer treatments show that the highest $\mathrm{K}$ uptake among fertilized treatments was given by ammonium sulphat followed by ammonium nitrate then urea. There was significant interaction with urea and ammonium nitrate of similar in $\mathrm{I}_{2}$ under drip irrigation system in second season. Increased irrigation by the $I_{2}$ in comparison with $I_{1}$, caused increased in yield of lettuce. The extent in yield increase seemed considerable to a level which led to increased uptake of N, P and K. This occurred despite the decreased contents of some macronutrients. Increased soil moisture seemed to have facilitated availability of $\mathrm{K}$ since with increased irrigation there was an increase in K-uptake. Podstawka and Malicki (1997) found that irrigation increased $\mathrm{P}$ accumulation, although this reduced $\mathrm{N}$ accumulation. Das and Banerjee (1996) reported that fertilizing with equivalents of $83 \mathrm{~kg} \mathrm{~K}$ in combination with $160 \mathrm{~kg} \mathrm{~N}+44 \mathrm{~kg} \mathrm{P} / \mathrm{f}$ caused highest uptake of $\mathrm{N}, \mathrm{P}$ and $\mathrm{K}$ nutrients. 
Table (11): Effect of irrigation systems, available soil moisture depletion and nitrogen fertilization on uptake $\mathrm{K} \mathrm{mg} /$ plant during 2013/14 and 2014/15.

\begin{tabular}{|c|c|c|c|c|c|c|c|c|c|}
\hline \multirow{3}{*}{\multicolumn{2}{|c|}{\begin{tabular}{|l|}
$\begin{array}{l}\text { Irrigation } \\
\text { treatment }\end{array}$ \\
Irrigation \\
systems
\end{tabular}}} & \multicolumn{8}{|c|}{ Nitrogen fertilization } \\
\hline & & \multicolumn{4}{|c|}{ Season $2013 / 2014$} & \multicolumn{4}{|c|}{ Season 2014/2015 } \\
\hline & & \multirow{2}{*}{$\frac{\mathbf{U}}{2182 \mathrm{e}}$} & \multirow{2}{*}{$\begin{array}{c}\text { AN } \\
2084 \mathrm{f}\end{array}$} & \multirow{2}{*}{\begin{tabular}{|c|c} 
AS \\
$2573 \mathrm{c}$
\end{tabular}} & \multirow{2}{*}{\begin{tabular}{|l} 
Mean \\
$2280 \mathrm{D}$
\end{tabular}} & & AN & AS & Mean \\
\hline Drip & $l_{1}$ & & & & & $2366 \mathrm{e}$ & $2350 \mathrm{e}$ & $2872 b$ & 2529B \\
\hline Irrigation & $\mathrm{I}_{2}$ & 2297d & $2581 \mathrm{c}$ & $3151 a$ & $2677 \mathrm{~A}$ & $2529 \mathrm{c}$ & $3042 a$ & $3012 a$ & $2861 \mathrm{~A}$ \\
\hline \multicolumn{2}{|c|}{ Mean (A X C) } & 2240D & $2333 \mathrm{C}$ & $2862 B$ & $2478 \mathrm{~A}$ & 2447D & 2696B & $2942 A$ & $2695 \mathrm{~A}$ \\
\hline Surface & $\mathrm{l}_{1}$ & 1997gh & $2036 . \mathrm{g}$ & $2928 b$ & $2320 \mathrm{C}$ & $1713 i$ & $1946 \mathrm{~g}$ & 2458d & 2039D \\
\hline irrigation & $\mathrm{I}_{2}$ & $1982 h$ & $2323 d$ & $2909 \mathrm{~b}$ & 2405B & $1875 \mathrm{~h}$ & $2142 f$ & 2837b & 228 \\
\hline \multicolumn{2}{|c|}{ Mean $(A \times C)$} & $1990 \mathrm{~F}$ & $2179 \mathrm{E}$ & $2919 A$ & 2363B & $1794 \mathrm{~F}$ & 2044E & $2647 \mathrm{C}$ & $2162 \mathrm{~B}$ \\
\hline Grand mean & & $2115 C$ & 2256B & $2891 \mathrm{~A}$ & & $2120 \mathrm{C}$ & $2370 \mathrm{~B}$ & $2794 \mathrm{~A}$ & \\
\hline \multicolumn{10}{|c|}{ Means of irrigation treatments } \\
\hline Mean & $I_{1}$ & $2090 \mathrm{E}$ & $2060 \mathrm{~F}$ & 2751B & $2300 \mathrm{~B}$ & $2039 F$ & $2148 \mathrm{E}$ & 2665B & 2284B \\
\hline$(B \times C)$ & $\mathrm{I}_{2}$ & $2140 \mathrm{D}$ & $2452 C$ & $3030 \mathrm{~A}$ & $2541 \mathrm{~A}$ & 2202D & $2592 \mathrm{C}$ & $2924 \mathrm{~A}$ & $2572 \mathrm{~A}$ \\
\hline \multicolumn{10}{|c|}{$\begin{array}{l}\text { Notes : } I_{1}: \text { Irrigation when } 50 \% \text { of available soil moisture is depleted. } \\
I_{2} \text { : Irrigation when } 25 \% \text { of available soil moisture is depleted. } \\
U \text { : urea }(46 \% \mathrm{~N}) \text {. } \\
\text { AN : ammonium nitrate }(33.5 \% \mathrm{~N}) \text {. } \\
\text { AS : ammonium sulphate }(20.6 \% \mathrm{~N}) \text {. }\end{array}$} \\
\hline
\end{tabular}

Total Chlorophyll contents:

Chlorophyll analyses of the fresh leaves are shown in Table 12. The main effects of irrigation system show that drip irrigation gave the higher value than surface irrigation. Under drip irrigation data show that decreasing the soil moisture (by prolonging irrigation intervals) resulted in increase the concentration of total chlorophyll. While under surface the greatest concentration of total chlorophyll was given by $\mathrm{I}_{2}$ and the lowest was that of the $I_{1}$. There was interaction with fertilizer treatment: where ammonium nitrate or urea was used, the $I_{1}$ dry and $I_{2}$ medium regimes were similar under drip irrigation in the second season.

However, there was an interaction with moisture regime plants supplied with $\mathrm{U}$ or $\mathrm{AN}$ were rather similar and $\mathrm{U}$ or $\mathrm{AS}$ in season 1 and 2, respectively under $I_{2}$ medium regimes under drip irrigation system. Shafshak (1987) reported that AS gave more chlorophyll contents over urea in spinach. $\mathrm{N}$ fertilization was reported to have increased concentration of chlorophyll in fresh leaves of spinach . 
Table (12): Effect of irrigation systems, available soil moisture depletion and nitrogen fertilization on total chlorophyll $\mathrm{mg} / \mathrm{L}$ during 2013/14 and 2014/15.

\begin{tabular}{|c|c|c|c|c|c|c|c|c|c|}
\hline \multirow{3}{*}{\multicolumn{2}{|c|}{\begin{tabular}{|l|}
$\begin{array}{l}\text { Irrigation } \\
\text { treatment }\end{array}$ \\
$\begin{array}{l}\text { Irrigation } \\
\text { systems }\end{array}$ \\
\end{tabular}}} & \multicolumn{8}{|c|}{ Nitrogen fertilization } \\
\hline & & \multicolumn{4}{|c|}{\begin{tabular}{|l|l|} 
Season $2013 / 2014$ & \\
\end{tabular}} & \multicolumn{4}{|c|}{ Season 2014/2015 } \\
\hline & & $\mathbf{U}$ & AN & AS & Mean & $\mathbf{U}$ & AN & AS & Mean \\
\hline Drip & $\mathrm{l}_{1}$ & 278.3a & $250.5 \mathrm{bc}$ & 216.7de & $248.5 A$ & 195.9ab & $206.3 a$ & $186.7 \mathrm{~b}$ & 196.3A \\
\hline Irrigation & $\mathrm{l}_{2}$ & $251.3 b c$ & $258.8 b$ & $201.1 \mathrm{e}$ & $237.1 B$ & 198.1ab & $156.6 \mathrm{~cd}$ & $198.5 \mathrm{ab}$ & $184.4 \mathrm{~B}$ \\
\hline \multicolumn{2}{|c|}{ Mean (A X C) } & $264.8 \mathrm{~A}$ & $254.6 \mathrm{~A}$ & $208.9 \mathrm{C}$ & $242.8 \mathrm{~A}$ & $197.0 \mathrm{~A}$ & $181.5 \mathrm{BC}$ & $192.6 \mathrm{AB}$ & 190.4A \\
\hline Surface & $\mathrm{l}_{1}$ & $150.5 f$ & $219.8 d$ & $250.9 b c$ & $207.1 \mathrm{C}$ & 108.0e & $141.3 d$ & $185.1 \mathrm{~b}$ & $144.8 \mathrm{D}$ \\
\hline irrigation & $\mathrm{I}_{2}$ & 204.9de & $236.8 c$ & $259.5 b$ & $233.7 \mathrm{~B}$ & $146.7 d$ & 189.6ab & $165.8 \mathrm{c}$ & $167.3 \mathrm{C}$ \\
\hline \multicolumn{2}{|c|}{ Mean $(\mathrm{A} X \mathrm{C})$} & 177.7D & $228.3 B$ & $255.2 A$ & 220.4B & 127.3E & 165.4D & 175.4CD & \\
\hline \multicolumn{2}{|c|}{ Grand mean $(\mathrm{C})$} & $221.2 \mathrm{C}$ & $241.5 \mathrm{~A}$ & 232.1B & & $162.2 \mathrm{C}$ & 173.5B & $184.0 \mathrm{~A}$ & \\
\hline \multicolumn{10}{|c|}{ Means of irrigation treatments } \\
\hline \multicolumn{10}{|c|}{\begin{tabular}{|l|l|l|l|l|l|l|l|l|l|} 
Mean & $\mathrm{l}_{1}$ & $214.4 \mathrm{C}$ & $235.2 \mathrm{~B}$ & $233.8 \mathrm{~B}$ & $227.8 \mathrm{~A}$ & $151.9 \mathrm{C}$ & $173.8 \mathrm{~B}$ & $185.9 \mathrm{~A}$ & $170.6 \mathrm{~A}$ \\
$(\mathrm{~B} \times \mathrm{C})$ & $\mathrm{I}_{2}$ & $228.1 \mathrm{~B}$ & $248.8 \mathrm{~A}$ & $230.3 \mathrm{~B}$ & $235.4 \mathrm{~A}$ & $172.4 \mathrm{~B}$ & $173.1 \mathrm{~B}$ & $182.1 \mathrm{AB}$ & $175.9 \mathrm{~A}$ \\
\end{tabular}} \\
\hline \multicolumn{10}{|c|}{$\begin{array}{l}\text { Notes : } I_{1}: \text { Irrigation when } 50 \% \text { of available soil moisture is depleted. } \\
I_{2}: \text { Irrigation when } 25 \% \text { of available soil moisture is depleted. } \\
\text { U : urea }(46 \% \mathrm{~N}) \\
\text { AN : ammonium nitrate, }(33.5 \% \mathrm{~N}) \\
\text { AS : ammonium sulphate }(20.6 \% \mathrm{~N}) \text {. }\end{array}$} \\
\hline
\end{tabular}

\section{REFERENCES}

Bremner J.M. (1965) Inorganic form of nitrogen in C.A. Black, D.D. Evans, L.E. Ensminger, J.L. White and F.E.Clark eds. Methods of soil analysis "Agron. Ser No.9, Am.Soc . Agron. Mad, Wiseonson, U.S.A.

Brown, L. R. (1999). Feeding nine billions. In L. Storke (Ed. State of the world (1999). Norton and New York p.230.

Brumm, I. and M. Schenk (1993). Influence of nitrogen supply on the occurrence of calcium deficiency in field grown lettuce. Acta Hortic., 339:125-136.

Bucks, D.A., L.J. Erie, and O.R. French. (1974). Quantity and frequency of trickle and furrow irrigation for efficient cabbage production. Agron. J. 66(1):53-57.

Bucks, D.A., L.J. Erie, O.F. French, F.S. Nakayama, and W.D. Pew (1980). Subsurface trickle irrigation management with multiple cropping Trans. Amer. Soc. Agr. Eng. 24(2):1482- 1489.

Chapman, H. D. and F. Pratt (1961): Methods of Analysis for Soils, Plants and Water. Univ. of Calif: 35 (5): 6-7.

Cottenie, A., M. Verlo, L. Kiekeus, G. Velghe, R. Camerlynck (1982). Chemical Analysis of plants and soils. Laboratory of Analytical and Agrochemistry State University, Ghent-Belgium.

Das, S. K. and N. C. Banerjee (1996). Nutrient uptake of crops and fertility status of soil at different mancrial treatments tuber potato based crop sequences. Potato Abst., 21 (4): 180.

Eissa, S.H. and F.L. Header (1991) Effect of nitrogen nutrition on lettuce. Minufiya J. Agric.Res. 16 (1):93-104 
FAO. (1979). Yield response to water. Irrigation and Drainage Paper No. 33. Rome, Italy.

FAO. (1984). Food and Agriculture Organization of the United Nations Rome, Italy.

Jackson, M. L. and A. Ulrich (1959). Analytical methods for use in plant analysis. Coll. Of Agric. Exp. State Bull.766: 35 pp.

Jensen, M.E. (1983). Design and operation of farm irrigation systems. Amer. Soc. Agric. Eng. Michigan, USA, p. 827.

Kucukyumuk, C.; E. Kacal; A. Ertek; G. Ozturk and Yasemin S. K. Kurttas (2012). Pomological and vegetative change during transition from flood irrigation to drip irrigation: Starkrimson apple cv. Scientia Hort., 136: 17-23.

Khalil, M.A.. I; M.Z. Sitohy and K.F. Mousa, (1985) Effect of water supply, GA3 and their interaction on spanich plants. Annals of Agric . Sc., Moshtohor, 23 (3) : 1287-1299.

Klute, A., (1986). Methods of Soil Analysis: Part I: Physical and Mineralogical Methods. (2nd Ed), Am. Soc. Agron. Monograph No. 9, Madison, Wisconsin. USA.

Meleha, M.I. (1992) Effect of inter-cropping of soybean with corn on yield and water consumptive use . M.Sc . Thesis Fac. of Agric ., Mansoura Univ

Michael, A.M. 1978. Irrigation theory and practice. Vikas Publishing House PVTLTD New Delhi, Bombay

Murphy, J. and J. P. Reily (1962): A modified single method for the determination of phosphorus in natural water. Anal. Chemi. Acta, 27:31-36.

Önder, S.; R. Kanber; D. Onder and B. Kapur (2005). The differences of possibility of global climate changing on irrigation methods and management techniques. In: GAP IV Congres of Agric.: 21-23 Sep. 2005 pp. 113-1128.

Page, A.L., R.H. Miller and D.R. Keeny (1982). Methods of Soil Analysis, Part II.Chemical and Microbiological Properties. (2nd Ed), Am. Soc. Agron. Monograph No. 9, Madison, Wisconsin, USA.

Podstawka-Chmiehvska, E. and Malicki (1997). Reaction of potatoes to spray irrigation and nitrogen fertilizer on light soil. Annals-Univcrsitaura. 52:77-83

Sammis, T.W. (1980). Comparison of sprinkler, trickle, subsurface, and furrow irrigation methods for row crops. Agron. J. 72(5):701-704.

Sanchez, Ch. A. (2000). Response of lettuce to water and nitrogen on sand and the potential for leaching of nitrate-N. HortScience, 35 (1):73-77.

Shafshak, N. S. and F.A. Abo Sedera, (1990) Effect of different nitrogen sources and levels on growth yield and nitrate accumulation in some lettuce varieties. Annals of Agric . Sci., Moshtohor ,28 (1): 619-631.

Shafshak, N. S. (1987). Showed greater K-contents in spinach receiving urea in comparison with those receiving ammonium sulphate.Annals of Agric . Sci., Moshtohor ,25 (3) : 1613-1625 
Stackman, W.P. (1966). Determination of pore size by the air bubbling pressure method proceeding unesce Symp on water in the unsaturated zone 366- 372

Türkmen Ö, M.A. Bozkurt, M. Yıldız and K.M. Çimrin (2004). Effect of nitrogen and humic acid applications on the head weight, nutrient and nitrate contents in lettuce. Adv. Food Sci. 26(2): 59-63.

Thompson T.L. and T.A. Doerge (1996). Nitrogen and water interactions in subsurface trickle-irrigated leaf lettuce. I: Plant response. Soil Sci. Soc. Am. J. 60(1): 163-168.

Tan C.S. (1995). Effect of drip and sprinkle irrigation on yield and quality of five tomato cultivars in Soutwestern Ontario. Can. J. Plant Sci. 75:225230.

Waller, R.A. and D. B. Duncan (1969). A basic rule for the symmetric multiple comparison problem. Amer.Statis.Assoc.J.12:1485-1503.

Wettsteine , D . (1957) Chlorophyll, letal under submikro skopische Formwech Sell der Plastiden . Exptl. Cell. Res, $12: 427$.

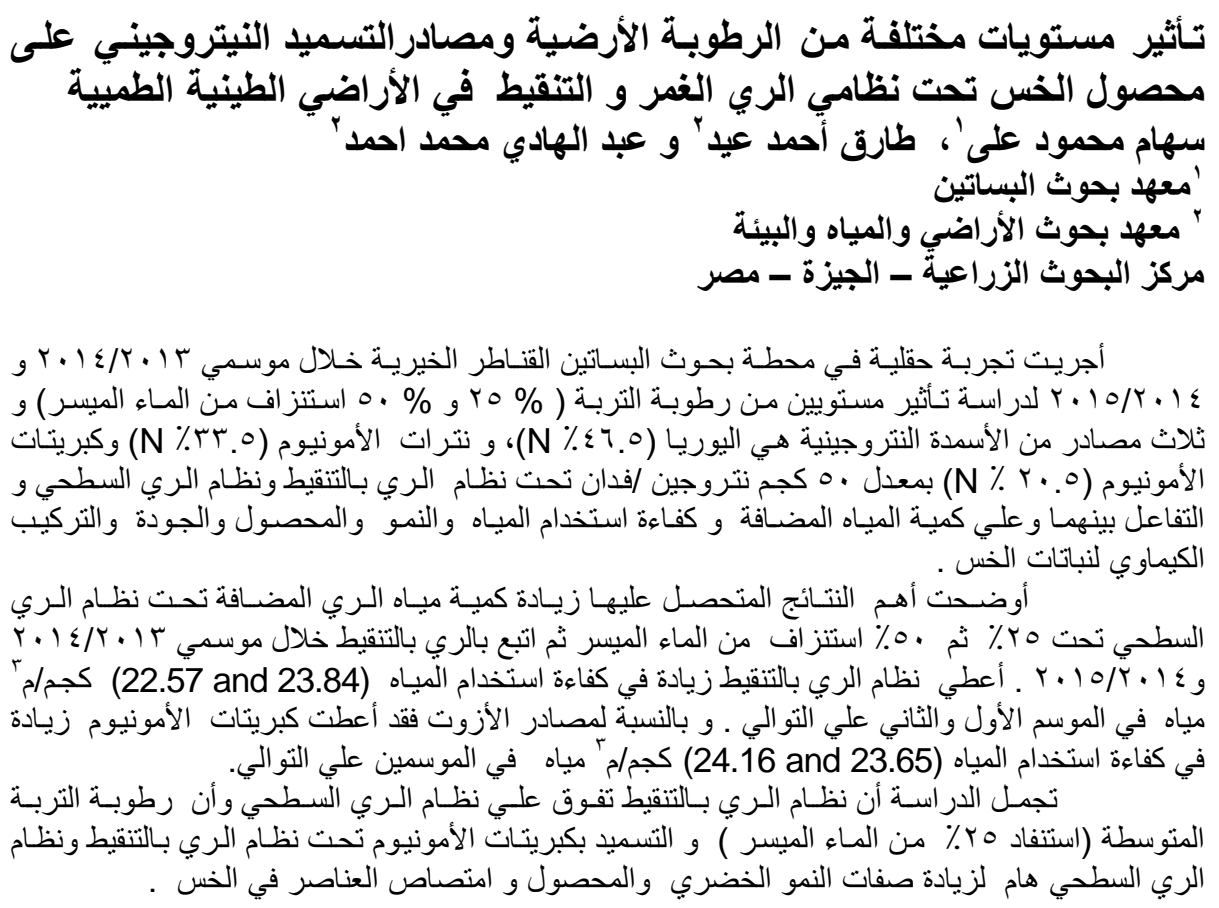

